\title{
MARIA ŚWIĄTKIEWICZ-MOŚNY \\ Papież umiera na blogu. \\ Analiza zapisków w pamiętnikach internetowych po śmierci Jana Pawla II
}

Śmierć Papieża-Polaka, Jana Pawla II, poprzedzona jego choroba, cierpieniem, umieraniem na oczach świata stala się przyczynkiem do „narodowych rekolekcji”. Pierwsze tygodnie kwietnia przepelnione byly nadzieja że „coś” dobrego się zdarzy, że „coś” się zmieni na lepsze. Media kreowaly atmosferę niezwyklości i wyczekiwania. Radio grało muzykę poważną i refleksyjna, w telewizji częściej dyskutowali księża i zakonnice niż politycy, nie emitowano reklam, gazety pokazywaly zdjęcia z „bialych marszów”, drukowaly specjalne „dodatki” o Papieżu, a portale internetowe przyjęly żalobne barwy. Media sugerowaly, że wszyscy Polacy przeżywają to samo i w ten sam sposób: w smutku spędzaja cale dnie przed telewizorem, lub uczestnicza w mszach świętych i nabożeństwach, zapalają świeczki w oknach. Za oknem, poza szklanym ekranem życie toczylo się dalej. $W$ radiu $B s^{1}$, na przyklad, mlodzi ludzie wyrażali swój sprzeciw wobec żaloby narodowej, argumentując, że Papież wcale wielki nie byl. Nie przebierając w slowach sluchacze radia żądali przywrócenia normalności, informowali się wzajemnie gdzie można się zabawić, mimo żaloby, którą porównywali do wojny, czy stanu wojennego.

Rola Jana Pawla II jest nie do przecenienia i to zarówno w kwestiach religijnych, spolecznych jak i politycznych. Ogrom Jego pracy z pewnością będzie widoczny jeszcze przez wiele lat, a zapoczątkowane zmiany będą kontynuowane.

\footnotetext{
${ }^{1}$ Audycja PR BIS, nadawana wieczorem, 4. kwietnia 2005 r. Radio BIS to rozglośnia polskiego radia skierowana do młodego słuchacza. Polskie Radio BIS reklamuje się hasłem „Bardzo Inna Stacja" oraz ,tani lans nie ma szans".
} 
Celem tej pracy nie jest analiza dziela Papieża-Polaka, a raczej próba kategoryzacji zapisków w pamiętnikach internetowych po śmierci Jana Pawła II, co może posłużyć do zrekonstruowania obrazu przeżywania żaloby przez Internautów. Obraz ten powstanie ze spontanicznego opisu doświadczania śmierci papieża, nieocenzurowanych przez twórców programów telewizyjnych, czy radiowych, pisanych w zaciszu domowym, z założenia autentycznych.

Obecność mediów podczas umierania Jana Pawła II byla naturalną konsekwencja ,polityki" przez Niego prowadzonej. Ksiądz Federico Lombardi, SJ, dyrektor Watykańskiego Ośrodka Telewizyjnego, w ćwierćwiecze pontyfikatu podkreślal, że Papież przywiązywal ogromną wage do mediów, z szacunkiem i cierpliwością traktowal dziennikarzy. Jan Pawel II wiedzial w mediach ,istotny wymiar współczesnej rzeczywistości, byt przeświadczony, że upowszechnienie jakiegokolwiek przestania jest nie do pomyślenia bez udzialu mediów. (...) Papież stara się rozumieć i brać pod uwagę $w$ swojej pracy mechanizmy przekazu informacji w dzisiejszym świecie, bynajmniej się ich nie lęka ani im się nie podporzqadkowuje" (www.opoka.org.pl/biblioteka/T/TH/THO/25jp/lombardi_media. $\mathrm{html})^{2}$.

Media niemalże minuta po minucie relacjonowaly umieranie Jana Pawła II, a ich rola w tym czasie nie ograniczyla się do informowania, relacjonowania wydarzenia. Widzowie i shuchacze mogli mieć poczucie, że wspóluczestniczą w Jego umieraniu, jak najbliżsi przyjaciele. Również dzięki mediom zaistniała możliwość podzielenia się swoimi przeżyciami, przemyśleniami, uczuciami z szerszą publicznością oraz porównanie swoich doświadczeń z doświadczeniami innych, którzy poprzez media masowe wyrażali swoje emocjami. Szczególną rolę odegral Internet - globalna sieć, która z natury jest miejscem swobodnych wypowiedzi, stała się swoistym ,wentylem bezpieczeństwa”, przez który uciekały emocje, żal, smutek, cierpienie, ale także złość, czy irytacja. Portale internetowe przyjęly żalobne barwy, uruchomiono cyfrowe księgi kondolencyjne, fora dyskusyjne zapelnily się żałobnikami, za pomocą komunikatorów wysylano informacje o mszach świętych, nabożeństwach, „bialych marszach”. Media wykreowaly ogólnonarodową atmosferę żałoby, podniosłego smutku i oczekiwania.

Śmierć Papieża zaktywizowała pokłady emocji, często glęboko skrywanych przed otoczeniem, albo nieuświadomionych. Ich wyrażenie stało się nie tylko możliwe, ale nawet powszechne. Zapalanie świeczek w oknach, uczestnictwo w „bialych marszach”, nabożeństwach, wspólnych modlitwach byly w tamtych dniach dzialaniem masowy, tak przynajmniej relacjonowaly to media nadajac legitymizację każdemu jednostkowemu wyrażaniu żalu po śmierci Jana Pawła II.

\footnotetext{
${ }^{2}$ Wszy stkie teksty internetowe były dostępne 20.11.2005 r.
} 
Analizie zostaną poddane wypowiedzi internautów na blogach, czyli w pamiętnikach internetowych, które są rodzajem swobodnej twórczości osobistej pisanej dla szerokiej i często nieznanej rzeszy czytelników. Pamiętniki internetowe służą autoprezentacji, kreowaniu swojej tożsamości w wirtualnej przestrzeni oraz prezentowaniu siebie znajomym ,,z reala”. Kto i w jaki sposób wyraził żal po śmierci papieża na swoim blogu? Czy zapaleniu świeczki - symbolu ,[]" towarzyszyla jakakolwiek inna forma „poza - sieciowego" przeżywania śmierci Papieża i czy bylo to na tyle ważne autoprezentacyjnie, żeby o tym opowiedzieć w wirtualnej przestrzeni?

Z czterech serwisów blogowych, które prowadzą rankingi popularności zostaly wybrane najpopularniejsze: http://nigri.blog.pl, http://blog.tenbit.pl/gifvpaulii. http://fanaberia-qurrr.blog.onet.pl, http://rozmawiamy.blox.pl, które byly aktywne w kwietniu 2005 oraz blog ekspercki prowadzony przez Marię Cywińska-Milonas (www.lumpiata.blog.pl), socjologa Internetu. W sumie analizie zostaly poddanych 101 blogów.

Na popularności bloga składa się ilość komentarzy jakie odwiedzający go zostawiaja pod każdą notka. Najpopularniejsze pamiętniki mają najwięcej czytelników i w pewnym sensie są wzorotwórcze ponieważ inni blogowicze naśladują sposób pisania najpopularniejszych autorów (Parzuchowski, 2002). Wybrane blogi nie stanowią reprezentatywnej części spoleczeństwa, nie można na ich podstawie wnioskować o tym, czy wszyscy mlodzi ludzi są religijni, czy też nie. Analiza blogów pokaże, jaka jest zależność pomiędzy prezentowanym na blogu smutkiem po śmierci papieża, a (prezentowaną również na blogu) religijnością $i$ kościelnością. Kto i w jaki sposób wyrazil żal po śmierci Jana Pawla II na swoim blogu? Czy jest możliwe odtworzenie przeżywania żaloby w „realu”?

\section{Autoprezentacyjne możliwości pamiętników internetowych}

Z notatek prasowych można wywnioskować, że blog to rodzaj pamiętnika internetowego, często aktualizowanej strony internetowej, z wpisami opatrzonymi datami. Nazwa pochodzi o angielskiego weblog. Maria Cywińska-Milonas, socjolog internetu, na swoim blogu (www.jej.notatnik.net) zamieszcza następujace definicje bloga: rodzaj niezredagowanej, autentycznej ekspresji siebie; blyskawiczne narzędzie publikacji; często aktualizowany dziennik on-line; amatorskie dziennikarstwo; coś, co zrewolucjonizowalo globalnq sieć; narzędzie uczqce uczniów i studentów pisać; nowy sposób komunikowania się z klientami; nowy sposób zarzqdzania wiedza w wielkich korporacjach; coś, czego nie chcesz, zeby przeczytala twoja mama; coś, o czym rozmawia się na imprezach; glupi wyraz, który jest śmieszny w wymowie (www.jej.notatnik.net). 
Z perspektywy spolecznej blog może być rozumiany jako rodzaj komunikowania $i$ to przede wszystkim komunikowania siebie, czyli autoprezentacji. $\mathrm{Na}$ wirtualnym targowisku (Parzuchowski, 2002) blogowicze przekrzykuja się swoimi doświadczeniami, przeżyciami, zachęcając $\mathrm{w}$ ten sposób do odwiedzenia swojej strony.

Pamiętnik internetowy sklada się nie tylko z treści, zamieszczanych notatek opatrzonych datą oraz szablonu, który niczym stój jest rodzajem fasady osobowości autora. Równie ważną częścia bloga sa komentarze i księga gości, które slużą przede wszystkim komunikacji między czytelnikami, a twórcą; nazwa, czyli Nick, pseudonim, który jest rodzajem autodefinicji stworzonej na potrzeby sieci; archiwum, w którym magazynowane notatki; oraz linki do innych blogów, czytanych przez autora, które tworzą tzw. blogsferę. Liczba komentarzy przeklada się na atrakcyjność oraz popularność pamiętnika, a ich brak oznacza śmierć bloga. Między osobami piszącymi pamiętniki istnieje nawet swoista rywalizacja ile komentarzy pojawi się na blogu, ile wskaże licznik gości. Na tej podstawie można tworzyć socjometryczne sieci atrakcyjności, czy popularności poszczególnych blogów.

Pisanie bloga odbywa się na ogół w warunkach sprzyjających większej otwartości w wyrażaniu emocji. Większość pamiętników internetowych powstaje w zaciszu domowym, na ogól bez świadków co ,zmniejsza skłonność do samokrytycyzmu, nieśmialości czy zaklopotania" (Parzuchowski, 2002). Anonimowość, mimo, że jest ona w wielu przypadkach tylko pozorna, (bo bardzo latwo jest „wytropić" autora bloga i sprawdzić kim jest w rzeczywistości), dodaje odwagi do pisania o sprawach intymnych, czy bolesnych, skłania do większej otwartości, a także do pisania prawdy (Wallace, 2002).

Blogi moga też być rodzajem terapii. Wiadomo, że opisywanie w czasie przeszłym bolesnych doświadczeń, stresujących wydarzeń, czy trosk życia codziennego pozytywnie wplywa na zdrowie psychiczne i fizyczne (Parzuchowski, 2002). „Publikując intymne treści w Internecie, nadawca, by być zrozumialym, musi zadbać o wlaściwą formę swojej wypowiedzi. $Z$ badań profesora Jamesa $\mathrm{W}$. Pennebakera $z$ Uniwersytetu w Teksasie wynika, iż w tej metodzie autoterapii najwięcej zyskuja osoby, które tworza dobre opowiadania, używaja jasnej narracji, precyzują swoje doświadczenia emocjonalne i swój stosunek do nich. A zachowując anonimowość, możemy sobie pozwolić na przekazywanie głęboko skrywanych uczuć i pragnień, co - jak dowodzi badacz - zmienia wiele czynników psychofizycznych. Bloggerzy mogą więc być jedną z najzdrowszych grup w Internecie" (Parzuchowski, 2002). Opisując swoje emocje po śmierci Jana Pawla II internauci mieli okazję nazwać i uporządkować swoje uczucia, wyrazić je publicznie, ale $\mathrm{z}$ dużym poczuciem bezpieczeństwa jakie daje ekran monitora. W zsekularyzowanym świecie wyrażanie uczuć i prezentowanie postaw religijnych 
nie zawsze jest na miejscu. Jest „passe” wśród młodzieży, która ucieka z lekcji religii, jest tolerancyjna względem związków kohabitacyjnych, wspólżycia pozamalżeńskiego, farmakologicznych środków antykoncepcyjnych (Zdaniewicz, Zaręba 2005). Wyrażenie żalu po śmierci Jana Pawla II, mogloby przecież zostać odebrane jako solidarność z Kościolem - instytucja, której przewodzil przez 27 lat, a to w niektórych środowiskach mogłoby się spotkać z wyśmianiem, podczas gdy na blogu nie chciany komentarz można usunąć.

Pamiętniki internetowe tworzą specyficzna subkulturę, kreują styl życia, wplywają na indywidualne biografie, zarówno piszących jak i czytających. Spoleczności internetowe powstale $z$ sieci liniowych powiązań nierzadko sa podstawą przyjaźni w życiu pozasieciowym, znajomości, która oparta jest o podobne postrzeganie świata, a nie stanowiona poprzez miejsce zamieszkania, przynależność do klasy szkolnej, czy jednego zespolu w firmie.

Blogi to jedna z najdynamiczniej rozwijajacych się uslug internetowych. Joe Tippi, który w 2004 r. prowadzil kampanię prezydencką Howarda Deana twierdzi, że jak zaczynal prace na świecie bylo 4000 blogów, teraz jest ponad $20 \mathrm{mi}$ lionów, i wciąż ich przybywa (http://wiadomosci.onet.pl/1259947,720,kioskart. $\mathrm{html}$ ). Szacuje się, że w Polsce działa ponad milion pamiętników, co daje trzecie miejsce w świecie, za blogami pisanymi w języku angielskim i hiszpańskim (www.jej.notatnik.net).

Pamiętniki internetowe stwarzają nieograniczone możliwości autoprezentacji. Interakcyjny charakter Internetu umożliwia, komunikację, w której jeden nadawca zwraca się do grupy, często nieznanych mu osobiście osób, prezentując siebie, swoje doświadczenia codzienne, czy ważne wydarzenia za pomoca tekstu, fotografii i symboli, a odbiorcy udzielają informacji zwrotnej w „księgach gości” i „komentarzach". Autoprezentacja to próba zakomunikowania przez nasze wypowiedzi, zachowania niewerbalne i dzialania, kim jesteśmy, albo za kogo chcielibyśmy być uważani przez innych (Aronson i in., 1997, s. 245). Zatem konieczne jest istnienie tej drugiej osoby, na której chce się zrobić określone wrażenie. Internet daje duże możliwości kontrolowania i zarządzania wiedzą o samym sobie, $z$ drugiej strony informacje na temat partnerów interakcji nie zawsze sa wystarczające, żeby manipulacja wizerunkiem byla skuteczna. Autor pamiętnika może stosować podobne taktyki autoprezentacyjne, które dostępne są w „realu”, na przyklad: ingracjację, czyli plawienie się w cudzej chwale, w tym wypadku w popularności innego blogowicza, albo opisując swoje kontakty w środowisku pozasieciowym, zachowania konformistyczne wobec swoich czytelników oraz uleganie modom panującym na innych blogach.

Autor pamiętnika internetowego ma możliwość manipulowania swoim wizerunkiem, konstruuje coś co można nazwać e-tożsmościa, elektronicznym portre- 
tem, zbudowanym z cech prezentowanych na blogu i ksztaltowanych także pod wplywem środowiska sieciowego. Dzięki tym charakterystyką czytelnik może czynić zalożenia odnośnie autora. Autorzy analizowanych blogów reprezentowali cztery różne kategorie społeczne. „Fanaberia Qurrr” przedstawia się jako dziennikarka, która aktualnie pracuje w samorządzie. Na blogu zamieszcza tylko teksty związane z polityka. 19 z 20 linków to hiperlącza do blogów politycznych przede wszystkim wyborczych. Dostępu do tego jednego niepolitycznego linku broni ostrzeżenie: „blog może zawierać treści dozwolone od lat 18”. Polowa jej internetowych znajomych zaczęla pisać swój pamiętnik po kwietniu 2005, jednak wszyscy Ci, którzy blogowali wcześniej zamieścili informacje o śmierci Papieża. Ponieważ prawie wszystkie linki dotyczyly pamiętników ,politycznych", a ich autorzy przyjmują postawę dziennikarzy, którzy opisują rzeczywistość i komentują ja, notatki z początku kwietnia mialy charakter informacyjny. Autorzy nie wyrażali osobistego żalu, czy innych emocji, a raczej opisywali rzeczywistość spoleczną i polityczną powstałej w wyniku śmierci Papieża.

„Nigri” studiuje w Ośrodku Badań nad Tradycją Antyczną na Uniwersytecie Warszawskim. Linki, które umieściła na swoim blogu wiele mówią o jej zainteresowaniach (historia, sztuka, kultura antyczna). Spośród 4 znajomych, którzy w kwietniu 2005 r. prowadzili swojego bloga, 2 poświecilo swoje notki śmierci Papieża. Obydwa wpisy świadczyć mogą o zaangażowaniu religijnym autorów. W tekst wplecione są fragmenty przemówień Papieża, teksty kanonów z Taizé, a także informacje o czuwaniu modlitewnym.

Blog ,gify-paulii” jeden $z$ najpopularniejszych $w$ serwisie tenbit.pl, to przede wszystkim obrazki. Bardzo rzadko pojawia się jakikolwiek tekst. Forma tekstu może zdradzać, że autorka jest nastolatką (LuUuwAgA :D WaShNa WiAdOmOoŚ́ :D nOoOwA nOoTQa nA moOOim bLoOg: kOoMeNtOoJcle :D pRo$\left.\mathrm{OsHe}^{\wedge} \wedge \wedge\right)^{3}$. O wieku Pauli możemy też wnioskować na podstawie linków, które umieszcza na swojej stronie. Niektórzy jej Internetowi znajomi na sowich blogach podają daty urodzenia oraz opisują życie szkolne. Tylko 2 jej znajomych prowadzi blog dhużej i tylko jeden, „m-a-y-a92”, pisze o śmierci Papieża na swoim blogu (drugi blog nie byl aktywny w kwietniu, ze względu na karę, jaką na autora nałożyli rodzice).

Autorem „rozmawiamy.blox.pl” jest mama dwójki dzieci, która 2 kwietnia brala ślub kościelny - na blogu zamieściła zdjęcia. Jej znajomi to przede wszystkim rodzice, którzy w pamiętnikach opisują swoje dzieci oraz życie rodzinne. Tylko „taka-sobie-mama” wspomniala o śmierci Papieża. Bohaterem notki jest synek, który pyta, czym Papież pojechal do nieba.

\footnotetext{
${ }^{3}$ We wszystkich cytatach z blogów zachowałam oryginalną pisownię.
} 
Autorka blogu eksperckiego jest Maria Cywińska-Milonas, socjolog Internetu, jak sama się przedstawia. $\mathrm{O}$ autorce, która posługuje się pseudonimem „Lumpiata” bardzo dużo wiemy, ponieważ wśród licznych linków są też adresy jej rodziców, siostry i syna oraz hiperlink do jej „pamiętnika zawodowego" (http//:iei.notatnik.net). Jest absolwentka Uniwersytetu Warszawskiego. Znajomi „Lumpiatej” to ludzie wykształceni, przeważnie mieszkańcy Warszawy, wyjeżdżający na wakacje ze granicę, pracujący na eksponowanych stanowiskach. Prawie wszyscy, do których linki znajdują się stronie www.lumpiata.blog.pl, którzy prowadzili swój pamiętnik w kwietniu 2005 opisali wydarzenia związane ze śmiercią Jana Pawła II. Warto zauważyć, że nie wszystkie notki byly powodowane pozytywnymi emocjami w stosunku do Ojca Świętego. Do tej blogsfery oprócz praktykujących katolików (wśród zapisków w pamiętnikach znajdują się i takie, które opisują uczestnictwo w praktykach religijnych) należą również ateiści i osoby niewierzące, które krytycznie odnosily się do Papieża oraz do „szumu medialnego" jaki wywolala jego śmierć.

Pamiętnik internetowy stwarza możliwość kreowania siebie, swojego wizerunku, a prezentowane na blogu cechy tworzą e-tożsamość. Śmierć Papieża stała się bodźcem do zaprezentowania swojego stosunku do Jana Pawla II, a także do Kościola katolickiego i wiary.

\section{Umieranie i śmierć Papieża w zapiskach Internautów}

W Polsce najpopularniejsza „,blogowiskiem" jest blog.onet.pl (ponad 600 tysięcy blogów), ale blogi można też pisać na tenbit.pl (ponad 200 tysiące użytkowników), mylog.pl (80 tysięcy), blog.pl (72 tysiące), blogi.pl (40 tysięcy) oraz blox.pl (30 tysięcy), każdy z serwisów prowadzi usługi darmowe (można zalożyć pamiętnik za darmo, ale nie będzie on wolny od reklam) oraz serwisy platne.

Pamiętniki internetowe zapisywane są zazwyczaj treściami osobistymi, nawet intymnymi. Internauci dzielą się ze swoimi czytelnikami klopotami w szkole, pracy, opisuja życie rodzinne, spotkania z przyjaciólmi, relacjonują czytane książki, recenzują oglądane filmy, chwalą się nowymi zakupami. W większości treści dotyczą ich prywatnego życia, zdarzeń, w których autor bral udzial, osób, z którymi lącza go styczności bezpośrednie i sporadycznie (o ile nie sa to blogi pisane przez dziennikarzy, czy polityków) pojawiają się treści nawiązujące na przykład aktualnej sytuacji politycznej kraju, wydarzeń ze sfery kultury, czy sztuki. W takim kontekście pojawienie się notek dotyczących Jana Pawla II świadczy o tym, że nie byl on tylko bohaterem sfery publicznej, a raczej przynależał do otoczenia prywatnego, w którym relacje oparte sa na silnych związkach emocjonalnych. Tylko na 8 spośród analizowanych blogach, aktywnych w 
kwietniu (czyli takich, na których w kwietniu 2005 pojawialy się notki) nie zamieszczono informacji o śmierci Ojca Świętego. Papież był kimś ważnym, ,nasz papież”, pisali internauci, ,czuję jakby odszedl ktoś z mojej najblizszej rodziny”, „,ktoś kogo bardzo kochamy”. Dalsze analizy pokaża jaka jest zależność między tak wyrażanym uczuciem względem Jana Pawła II, a prezentowaną religijnością.

\section{Wyrażenia żalu po śmierci Jana Pawla II a deklarowana religijność}

Wyrażenie żalu, głębokiego smutku po śmierci Jana Pawła II nie zawsze bylo wyrazem solidarności, czy przynależności do Kościola katolickiego, któremu przewodzil przez prawie ponad ćwierć wieku. We wszystkich blogsferach znalazly się osoby, które mimo definiowanie siebie jako ateista, osoby niezwiązane $z$ Kościolem czuly powinność podzielenia się ze swoimi czytelnikami żalem i bólem oraz wyrażenia swojego podziwu względem Papieża.

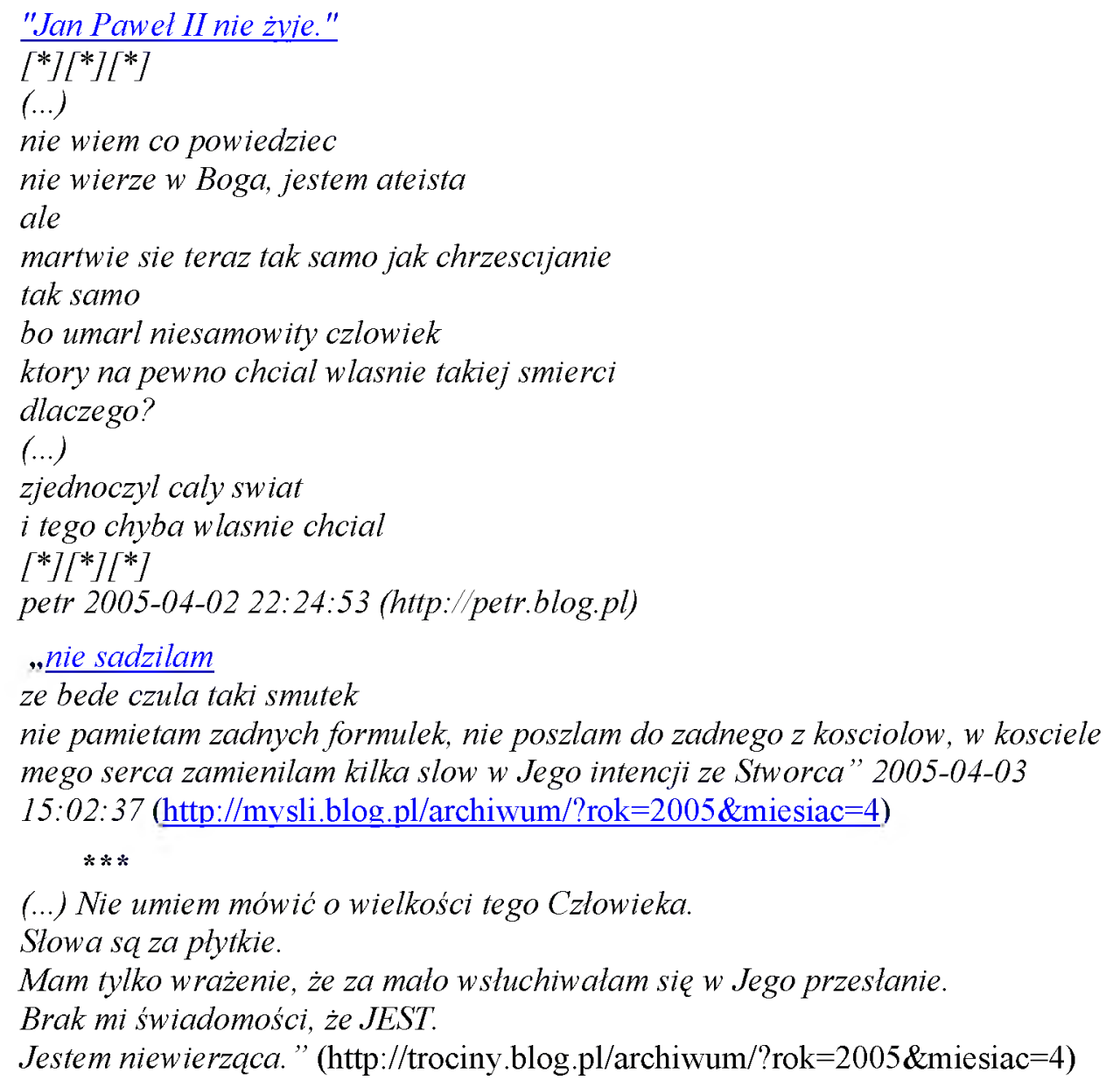


Wśród tych osób, deklarujących się jako nie praktykujące byli też tacy, którzy odwiedzili w tym czasie kościól, jak np. DOmisia.

||2005-04-07||23:07:00|| ||Muzyka na dziś: Papa Dance - Czarny śnieg||

„,...)Ale wiecie co jest piekne? Że śmierć tego wielkiego szlowieka nie poszla na marne. Ludzie, zwlaszcza mlodzi, porafili się zjednoczyć. Pokazać, że ten pontyfikat nie przeszedl bez echa... Że PApież dopial swego. I choćby taka DOmisia... Poszla dziśs do kościola pierwszy raz od dosc dlugiego (bardzo dlugiego) czasu. I nie po to, żeby być bliżej Boga, ale po to, by być blizej niego. Tego ktorego wszyscy tak kochalismy i kochac bedziemy. I to jest w tym wszystkim piekne." (http:/kocham--cie.blog.pl/archiwum/?rok=2005\&miesiac=4)

Podobnie Anabandyn:

„Jakaś cisza we mnie opustoszala...

Ja... niepraktykujaca...

Pójdę do Kościola...

czuje takq wewnętrzna potrzebę

pomodlić się za spokój jego duszy"

(http://glaukoma.blog.onet.pl/1.AR3 2005-04 2005-04-01 2005-04-30.in dex.html)

Warto zwrócić uwagę również na gradację i ważność Papieża. To dla Jana Pawła II DOmisia poszla do kościola, a nie po to, żeby być bliżej Boga. Podobnie Romantyczka wypowiadająca się na blogu gify-pauli twierdzi, że ,PAPIEZ JEST WSPOLCZESNYM JEZUSEM, ON NIE UMRZE NIESIE SWOJ KRZYZ, JAK JEZUS ALE JEZUS POKONAL SMIERC!!!! (http://blog.tenbit.pl/gifypaulii/10911)

Również Czerski, z wlaściwą sobie ironią zauważa, że najważniejszą osobą dla Polaków jest Papież „tym kraju, w którym od wielu lat na pierw szym miejscu jest matka boska, na drugim papież polak, na trzecim ostatnio james caviezel. a bóg ojciec poza podium" (http:/czerski.blog.pl)

$\mathrm{Na}$ blogach odnajdujemy również ślady uczestnictwa w zbiorowych formach celebrowania żałoby po zmarlym Ojcu Świętym.

,2.04.05, Przerośl

(...) (ludzie) Modla się - i to jest ważne. Matgorzata jest w Warszawie, opowiadata mi telefonicznie o petnym kościele ludzi na porannej mszy dziś rano. Ja siedzę w Przerośli, ale chyba wkrótce pojadę na popoludniowa mszę do Suwalk" (www.crwinski.blog.pl)

„A dziś podrzuciliśmy dzieciaki dziadkom a sami pojechaliśmy do krakowskich Dominkanów. I powiem tylko tyle, że warto bylo" (http://agnieszek.blog.pl) 
W pamiętnikach internetowych pojawily się zapiski, które nawiązują do śmierci Jana Pawla II, co można interpretować jako poddanie się dyktatowi mediów, szczególnie telewizji i radia. $Z$ drugiej jednak strony, wydaje się, że notki o Papieżu, powstawaly z poczucia obowiązku względem Jana Pawła II. Blogowicze deklaruja swoja oryginalność, indywidualność i potrzebę bycia autentycznym, czyli niezaklamanym (Parzuchowski, 2002). Można zatem przypuszczać, że opis jednostkowych doświadczeń po śmierci Papieża również byl autentyczny i niezakłamany i powstał $\mathrm{w}$ poczuciu głębokiej indywidualnej potrzeby, a nie narzuconego z zewnątrz przymusu.

Ilość notek wspominających Papieża nie może zostać potraktowana jako przyczynek do twierdzenia o wzroście religijności. Oprócz przytoczonych wcześniej cytatów, w których autorzy wyrażając żal i smutek po śmierci Jana Pawła II równocześnie deklarują ateizm usprawiedliwiaja się niejako przed swoimi czytelnikami redukując dysonans, który powstaje po zestawieniu pozytywnym stosunku do Papieża $z$ negowaniem nauki Kościoła, pojawiają się również takie wpisy, które wskazuja na brak refleksyjności nad stosunkiem do religii przy silnym poczuciu więzi z papieżem. Przykładem może być notatka m-a-y-a92 (prawdopodobnie 92 oznacza rok urodzenia, zatem autorka ma 13 lat), pisana w slangu mlodzieżowym.

„(...)P WcZoRaJ ByE pRiMa ApRiLiS.. i PaPiEz PoWoLi OdChOdZi oD NaS..:( WiDoCzNiE TaK MuSi ByC...( aLe To NiE JeSt ŻaRt..:( To pRaWdA...)( NiOm, DoBrA, To TeRaZ CoŚ z MoYeGo WcZoRaJ SHeGo dNia.. =)) (..) NaJpleRw To oPiShE.. =] PiErFsHA LeJbA.. To ByLa ReLa..=]J OoO.. SzYdErCia ByLa NiE MaLa. (..) PoTeM SiE NudZiLaM.=D i pLoShE WaS, MódLcle SiE Za PaPiEżA..:(( PoZdRoOfKy dLa FsHyStKiCh..=)) PaPa...* KoFfFaM WaS.. $=D "$ (http://blog.tenbit.pl/m-a-y-a92/12)

Prima Aprilis, umieranie Papieża, lekcja religii, na której, prawdopodobnie, m-a-y-a92 zachowywala się nie tak jakby oczekiwal nauczyciel, spotkanie ze znajomymi, zakupy, a na koniec prośba o modlitwę za papieża. Również komentarze wydaja się być zupelnie nieadekwatne do sytuacji. Kargul komentuje:" Papież rzeczywiście od nas odchodzi: (Strasznie dhuga notka:D Pozdrofoinka dla ciebie; * Aga*R*: ,ppież chory. bardzo:( Ciekawy dzień. Pozdro..."; Aniolecek: Jest mi very smutaskowo przez papieża... (..) tak dobrze szlo z komentkami to trzeba się postarać żeby dalej tak byto;) pozdrooffki for you :*:*.*:* No chyba że już nie będziesz prowadzila tego bloga.......??" (http://blog.tenbit.pl/m-a-ya92/12).

Notki, które pojawily się w czasie umierania i po śmierci Jana Pawla II na polskich blogach, ze względu na treść można podzielić na sześć kategorii. Pierwszą tworzą wszystkie treści, które odwolują się do emocji. Smutek, żal i cierpie- 
nie to najczęściej odczuwane i opisywane uczucia. Druga kategoria zostanie zbudowana ze wszystkich notek, które odwolują się do modlitwy. Część internautów zdefiniowala śmierć Jana Pawła II jako wydarzenie historyczne, które może zmienić losy świata, dlatego przeżywanie tego dnia zostało opisane w detalach, po to, żeby mlodsze pokolenia mialy możliwość uczestniczenia w tym dniu. Niektórzy autorzy dali wyraz swojemu oburzeniu na szum medialny, który powstal, sugerując jego nienaturalną spontaniczność. Wśród analizowanych pamiętników są również takie, które nie odnotowaly śmierci Papieża.

\section{Milość, smutek, żal i cierpienie}

Smutek, żal i cierpienie to najczęściej opisywane emocje na blogach po śmierci Papieża. „Lzy... lzy...lzy stojq w moich oczach" pisze Glaukoma (http:// glaukoma.blog.onet.pl/1,AR3 2005-04 2005-04-01 2005-04-30.index.html).

„Jest mi very smutaskowo przez papieza” pisze m-a-y-a92 (http:/blog.tenbit.pl/m-a-y-a92/12), a Paulinka dodaje: Kochamy bardzo Ojca Swiętego i zawsze bedziemy o Nim pamietac: $\left[{ }^{*}\right]\left[{ }^{*}\right]$ (http://blog.tenbit.pl/gifypaulii/10911)

Internet jest bardzo oszczędnym kanalem komunikacji. Emocje wyrażane są tu nie poprzez dlugie opisy, a często za pomoca emotikonów i akronimów. Na wielu blogach pojawily się symboliczne świeczki ['], lub [*] znane Internautom i zapalane przy okazji śmierci, która odnotowuja portale internetowe. Zapalona świeczka jest symbolem lączności z wszystkimi tymi, którzy po śmierci Papieża odczuwaja żałobę. Uruchomiono nawet specjalne strony, na których plonęly setki wirtualnych zniczy. Świeczki plonęly glównie w komentarzach, gospodarze blogów starali się by notatki w te dnia byly wyjątkowe (o ile na takie się zdecydowali). Używane na co dzień symbole okazaly się niewystarczające do opisania śmierci Jana Pawla II oraz wszystkiego co się w związku z tą śmiercią działo, a co w pojęciu autora bloga bylo warte zanotowania.

2005-04-02 Godzina 21:37... opuścil nas Jan Pawel II... byl jedyny w swoim rodzaju. Napetnil nasze serca miłościq...

['] ['] ['] ['] ['] ['] ['] ['] ['] ['] ['] ['] ['] ['] ['] ['] [']

...chwila ciszy. (http://deprived-o-dream.blog.pl)

Wśród innych emotikonów jakie pojawily się na blogach można wymienić „:" i ," obydwa wyrażajace smutek. Podobnie jak w przypadku świeczek ['] pojawialy się one raczej w komentarzach niż w notkach autorskich.

Po śmierci Jana Pawla II internauci opisywali na swoich blogach przede wszystkim emocje jakie wywołało to wydarzenia, oraz uczucia jakie żywili do 
Papieża. Wyrażeniu milości oraz smutku, żalu, bólu i cierpienia towarzyszyly emotikony przede wszystkim świeczki ['] i smutne miny ,,", ,„”.

\section{Modlitwa}

Po śmierci Papieża wiele osób zapragnęlo się pomodlić. Część autorów poszła do kościola, uczestniczyla w nabożeństwach i w ,bialych marszach”. Uczestniczenie w zbiorowych modlitwach nie było jednak zbyt popularne wśród Internautów. Częściej za to zamieszczali notki, które tytulowali „modlitwa”. Na przyklad Fabella napisala:

piatek, 01 kwietnia 2005

Modlitwa

,Jak wierzyc w sny bez konca

$W$ radosci nieskonczona nute

$W$ dni pelne goracego slonca?

Jak wierzyc?

Tak bardzo smutno kiedy Ktos odchodzi

Gdy zycie z czasem zegna sie

Z tesknota trudno sie pogodzic

I z zalem me modlitwe sle

Do Boga

14:33, fabella, http:/patunia.blox.pl html/1310721,262146,169.html?4

Gifi-pauli (http://blog.tenbit.pl/gifv-paulii) w swojej notce z 1. kwietnia prosi o modlitwę za Papieża, który wtedy byl już bardzo chory. W jednym z komentarzy „Kamcia_13” wyjaśnia dlaczego powinniśmy się modlić za Jana Pawła II:

,Módlmy się za Jana Pawla II

Wspaniatego czlowieka

którego uwielbiamy i kochamy

Dlaczego?

Bo on zawsze modlit się za nas

Bo zawsze mial dla nas czas

Bo podczas pielgrzymek pomimo zmęczenia, wyczerpania wychodzil i rozmawial z nami

Bo bardzo kocha mlodzież

Bo zjednoczyl wszystkie narody

Bo jest $z$ nami do końca

Bo będzie z nami zawsze, w naszych sercach

A więc i my zróbmy coś dla niego

$\left[{ }^{*}\right]$

Nie bój się 
Nie lękaj się

Bóg sam wystarczy" (http:/blog.tenbit.pl/gifv-paulii/10911)

Z kolei ,jusia_88" wpisuje treść modlitwy Zdrowaś Mario i dodaje: „Módlmy sie za Ojca Świętego. Jest to bardzo ważne ponieważ PAPIEŻ jest w ciężkim staniem Może Bóg uslyszy nasze proźby i PAPIEŻ wyzdrowieje Pokażmy na co stać Polskq mlodziez!!!" (http://blog.tenbit.pl/gifv-paulii/10911)

Internauci polecali duszę Jana Pawła II w modlitewnych westchnieniach (Panie świeć nad Jego dusza), lub prosili innych o modlitwę. Warto też zauważyć, że opisy uczestnictwa w nabożeństwa występuja tylko w blogsferze, czyli wśród znajomych „Lumpiatej”. Wśród 38 jej znajomych, na których blogach, aż 13 podzieliło się obecnością na nabożeństwach, mszach świętych, czy „bialych marszach".

\section{Wydarzenie historyczne}

Jan Paweł II był przywódcą religijnym i jako taki wywarl znaczący wplyw na losy świata. Życie Papieża, któremu nadano przydomek „Wielki” było bardzo bogate w uczestnictwo w wydarzeniach historycznych, dlatego oczekiwano, że Jego śmierć „,coś zmieni”. To „,coś” pozostaje niezdefiniowane i tylko dziennikarze, zawsze najszybsi w pościgu na „newsami” owo „coś” wypelniali wydarzeniami z życia publicznego, ale także prywatnego: zawieszenie broni przez kibiców Wisły Kraków i Cracowi, pojednanie prezydentów Walęsy i Kwaśniewskiego, wstrzymanie reklam w telewizji, obecność tlumów na „bialych marszach” i naprędce organizowanych mszach polowych oraz bardzo prywatne wydarzenia, które w jednostkowych biografiach pozostana definiowane jako cud, dar od zmarłego już Ojca Świętego.

Autorzy blogów również dają wyraz swojemu oczekiwaniu na wielkie wydarzenie. Przykladem niech będzie notka „dwudziesta pierwsza trzydzieści siedem. drugiego kwietnia".

„, a jeżeli Nowy Czlowiek zapyta nas kiedyś, co robit o $21: 37$ to ... najpierw wystuchat kurantów o dwudziestej pierwszej na Rynku i machat rękami i mówit „brrr dringg dringg phryyy” i spektakularnie się zachwycat. póziniej poszliśmy do Fary. Nowy Czlowiek czul powagę chwili i rozgladal się na boki z uwagq. (...) nasze drobne życie plynęlo nieświadomym rytmem. wykapaliśmy Nowego Czlowieka, polożyliśmy go spać, ja też zasnętam. dzielimy TEN smutek zmieszany z nadzieja, mówię Nowemu Człowiekowi na ucho, że Papież odszedl, nie chce się nam w to wierzyć." (http://zimno.blog.pl/archiwum-4).

Również w kategoriach wydarzenia, podkreślając za razem ogromną rolę Papieża w historii pisal Fartner: ,jakem żem pisal wcześniej - z mej strony sza- 
cun z mojego punktu widzenia glównie dlatego, iż rzucić wyzwanie historii (polityce) nie każdy potrafi, a już jemu sprostać to rzadkość niebywala (..) i tak idqc $i$ trochu rozmyślajac (melancholia mnie sie jednak ciut udzielila) jasna i radosna myśl zaświtala mi we glowie. przeta jutro obudzę się w innym kraju - po takim pospolitym ruszeniu sumień przecież nikt już nie będzie kradl, dawal lapówek, żyl nieuczciwie, źle bliźnim życzyl, nietolerancyjnym byl; za to każdy będzie m.in. sumiennie, dokladnie $i$ z godnościq swoja pracę wykonywat (tacznie z drogowcami). nawet mi się przez chwile mnie samego szkoda zrobila, żem ja nie z tej gliny ulepion. z ulic zniknq śmieci, napotkanego czlowieka każdy będzie wital ze sercem na dloni, życzqc mu jak najlepiej i oferujq̨ bezinteresowna pomoc. nie będzie już rozbojów, gwaltów, ni pijaństwa. nad wista wreszcie zapanuje lad $i$ szczęśliwość powszechna. (.) oficjalnie fartniento 2005-04-04 02:06:36" (http://fartner.blog.pl)

Podniosła atmosfera jaką kreowały media widoczna byla również na blogach. Internauci wyrażali swój podziw dla Papieża, ale także oczekiwali, że Jego śmierć stanie się bodźcem do zmian. Dzień śmierci, czyli jak wielu oczekiwało początek nowego lepszego świata, który już nie będzie mial odwagi być zly, to dzień warty zapamiętania, dokładnego opisania po to, żeby dzieci i następne pokolenia dokładnie wiedzialy co się wtedy działo.

\section{5. Życie toczy się dalej. Cisza, czy nic się nie stało?}

Niektórzy postanowili zamilknąć. Z braku stosownych słów, bądź chęci do podzielenia się swoimi wrażeniami. Inni uznali, ze „życie toczy się dalej” i w pamiętnikach pojawily się notki zupelnie nie związane ze śmiercią Papieża. Wśród analizowanych blogów, tylko w 8 autorów nie skomentowali w żaden sposób kwietniowych wydarzeń.

Llena na swoim blogu 3 kwietnia 2005 napisala: ,, w trakcie spaceru, poczuliśmy nagla potrzebę wypicia Belfastu zapakowalismy syna, wózek $i w$ drogę $i$ ...wszystko bylo zamknięte oprócz niezawodnej karmy i raczyliśmy się smoothiesem do spótki z Tymem a jemu podobaly się siedziska pod oknem" (http://llena. blog.pl/archiwum/? rok $=2005 \&$ miesiac $=4$ )

Przytoczona notatka pokazuja, że dla tych autorek życie toczylo się dalej. Nie wiemy, czy wiedzialy o śmierci Papieża, możemy jednak przypuszczać, że wiedzialy - korzystaly przecież z Internetu.

Brak wpisów w okolicach dnia 2 kwietnia 2005 r., mógl być spowodowany różnymi okolicznościami. Osoby piszące pamiętniki, nie codziennie zamieszczają nowe notki. Na ogół powodem zawieszenia jakiegoś tematu są silne emocje, wydarzenie w życiu codziennym, które Internauta uznal za ważne, ale częstotli- 
wość zawieszania wpisów zwiazana jest również z dostepem do Internetu. Zatem część blogowiczów, którzy nie zamieścili w tych dniach żadnych informacji mogli po prostu nie mieć dostępu do sieci.

Analiza blogów nie daje możliwości odpowiedzi na pytanie o motywy zamieszczenia, bądź nie zmieszczenia notatek nawiązujących do śmierci Jana Pawla II. Można podejrzewać, że część autorów nie miala dostępu do sieci, byli też tacy, którzy Internet traktują jako rozrywkę, a pierwszy tydzień kwietnia był dla nich czasem żaloby. Jak, np. „Teściowa” (http://zapiski-tesciowej.blog.pl), która napisala dopiero 5 kwietnia

„CLVI 2005-04-05 09:56:19

Staw kolanowy to tajemnica.

Jedni klękaja jak zawsze, inni z grzmotem i lomotem padaja na kolana, inni tylko tak trochę przykucaja..

Sq i tacy, którym nagle, niespodziewanie dla nich, same kolana się zginajq" (http://zapiski-teściowei.blog.pl)

Autorzy pamiętników Internetowych zazwyczaj nie komentują wydarzeń politycznych, kulturalnych, religijnych i spolecznych, chyba, ze przyjmują role dziennikarzy. Śmierć aktorów, polityków, sportowców rzadko jest powodem do napisania notatki. Jan Paweł II dla wielu okazal się kimś bardzo bliskim i napisanie o swoim żalu w pamiętniku bylo czymś równie oczywistym jakby podzielenie się smutkiem po straci kogoś z rodziny.

\section{Medialny szum}

Blogowicze dostrzegli również, że śmierć papieża stala się wydarzeniem medialnym, które opisywali w kategoriach „eventu”. Czerski na swoim blogu pisze, ,kiedy dojeżdżam na miejsce on jeszcze żyje, a przynajmniej tak wynika $z$ esemesów nadsyłanych przez siostre $w$ regularnych odstępach czasu. (...) w samochodzie marecki zauwaza nad wyraz przytomnie: ale teraz zarobiq wydawcy katoliccy! no i taka prawda" (http://czerski.blog.pl). Podobnie Fartner: "powrót mój byl się zsynchronizowat z wiadomym eventem (slowo użyte umystnie) transmitowanym wszędzie." (http://fartner.blog.pl)

Notatki odnoszące się do śmierci Papieża były często komentowane. Czytelnicy czuli powinność wypowiedzenia się, wyrażenia współodczuwania. Przykladem może być blog Zimno, na którym pod notatką o śmierci Papieża znajduje się aż 52 komentarze. Oprócz komentarzy, które wyrażaly żal po śmierci Jana Pawla II oraz potwierdzaly przekonanie o wyjatkowości dnia jego śmierci (med.: dziękuję, że to napisalaś. bo widzisz, nie wszyscy autorzy blogów mieli takie podejście. więc u ciebie potrzebowalam znaleźć właściwsze. i znalazlam). Pojawily się również takie, które informowaly o tym, że media byly przygotowane na śmierć 
papieża już dawno (Rafal: „Heleno w Polskim Radiu pólka z napisem "śmierć Papieża" stoi gotowa od 3 lat. Widzialem jq dziesiatki razy. To co bieżesz za spontaniczne reakcje często zmontowano kiedy Papież jeszcze żyl. Bieżecie udzial $w$ żenujacym spektaklu. Nie dostrzegacie fatszu"). Podobne informacje o wcześniejszym przygotowaniu mediów do tego wydarzenia odnajdujemy na innych blogach (www.babcia-malgosia.blog.pl. www.lumpiata.blog.pl. www. cywinski.blog.pl).

Podobna klótnia miala miejsce na blogu june (http://notatnik.net). Również tutaj Internauci, którzy byli krytyczni względem zachowania mediów w tym czasie, zostali ośmieszeni:

Kłótnię wywolal komentarz Przyczyn ,,nie zgadzam sie glównie na to, zeby o 7:30, w trzecim dniu festiwalu żaloby elton john śpiewal mi $w$ drodze do pracy "candle in the wind" i zeby nie byto od tego zadnej ucieczki poza ciszq. moze o to im zresztq chodzi. to byloby może jeszcze najrozsqadniejsze rozwiazanie" (http://notatnik.net $? p=515 \#$ comments). Pozostali Internauci poczuli się urażeni wyrazem „festiwal” jak również krytyką mediów. Greta napisala:

„Prorokowalam, że po śmierci papieża będziemy mieli monumentalnq, narodowq tragedię. I muszę wszystko odszczekać. I ludzie i media zachowuja się $z$ godnościq i dojrzale. Jest, jak na moje cyniczne oko, być powinno i wszystko we wlaściwych proporcjach. Zdziwitam się i zwracam honor" (http://notatnik.net/ ? $\mathrm{p}=515 \mathrm{Hcomments}$ ). Gorol podsumowuje dyskusję: "June po co sie $w$ dawac $w$ te dyskusje? Sa tacy dla ktorych nic sie nie stalo i dalej zyja swoimi codziennymi problemami. Pieniadze $i$ komercja to ich zycie i nic ponad to" (http:// notatnik.net ? $p=515$ \#comments).

Po śmierci Papieża media rozpoczęly nadawanie programu, który wpisal się w przeżywanie żaloby. Atmosfera medialna w pierwszym tygodniu kwietnia byla niezwykla, zupełnie odmienna od codziennej praktyki. Część Internautów nie wierzyla w szczerość mediów, czego wyrazem jest krytyka i próba dyskredytowania mediów poprzez ujawnianie informacji o wcześniejszych przygotowaniach do emisji programu po śmierci Papieża, wtedy kiedy Jan Pawel II jeszcze żyl. Taka postawa spotkala się z krytyką na blogach, a zachowanie mediów było akceptowane i chwalone.

***

Śmierć Papieża-Polaka poruszyla thumy. Zapelnily się kościoly, ludzie gromadzili się na nabożeństwach, czuwaniach modlitewnych, „,bialych marszach”, pokonywali niezliczone przeszkody i wyjeżdżali na pogrzeb do Rzymu. Wszystko to relacjonowaly media: telewizja, radio, prasa, portale internetowe. Dzięki nim pojawiła się okazja, żeby nie tylko śledzić wydarzenia, uczestniczyć w 
transmitowanych nabożeństwach i mszach świętych, ale także wyrażać swoje opinie i emocje. Uczestniczyć we wspólnocie.

Również Internauci poczuli potrzebę i powinność zaznaczenia w swoim pamiętniku śmierci Papieża. Analiza blogów pokazała, że blogowicze czuli się związani z Janem Pawłem II więzią emocjonalną. Byl on kimś bliskim, bardzo ważnym, kimś kogo się kocha i kimś kogo będzie brakowalo. Trudno jednak na tej podstawie twierdzić, że śmierć Papieża spowodowala nawrócenie, czy też wzrost religijności, czy udzialu w praktykach religijnych. Oczywiście nie można tego powiedzieć $z$ cala pewnościa, ponieważ obserwacji poddany jest jedynie ten fragment życia jednostki, który jest prezentowany na blogu. Jednak wśród tych, którzy deklarowali się jako ateiści, osoby niewierzące trudno jest znaleźć taka, która by o swoim nawróceniu napisala w swoim pamiętniku. Podobnie wśród autorów, którzy deklarowali, że dawno nie byli w kościele, a śmierć Papieża spowodowała, że poszli. Oni również nie informuja swoich czytelników, że wizyty w kościele staly się częstsze.

Warto jednak zauważyć, że wszystkie krytyczne wpisy (komentarz, czy notka) dotyczące zarówno Jana Pawla II, jak i „szumu medialnego wokól Jego śmierci" nie pozostawaly bez odpowiedzi. Na blogach wybuchaly klótnie majace na celu zdyskredytować postawę krytyczną wobec Papieża i przeżywania jego śmierci.

Na podstawie analizowanych blogów nie można wnioskować na temat całości spoleczeństwa. Generalizacja takie są nieuprawnione, ponieważ w pamiętnikach internetowych prezentowana jest tylko część osobowości autora, który manipuluje swoim wizerunkiem i tworzy jego elektroniczną postać. W ten elektroniczny wizerunek wpisalo się wyrażenie żalu, cierpienia i smutku po śmierci Jana Pawla II.

\section{Bibliografia:}

E. i in. Aronson: Psychologia spoleczna. Serce i umyst. Zysk S-ka. Poznań 1997.

M. P a rzu chow ski: Cierpienie młodego bloggera: funkcje ujawniania treści prywatnych $w$ Internecie. Wystapienie na konferencji w Poznaniu. „Festiwal psychologii 2002".

P. W all a ce: Psychologia Internetu. Rebis. Poznań 2002.

W. Zdaniewicz, H. Zaręba: Modzież Warszawy - pokolenie pontyfikatu Jana Pawła II. Warszawa 2005. 
T. Z a sę pa, R. Ch mura: Internet $i$ nowe technologie ku spoleczeństwu przyszlości. Edycja św. Pawla 2003.

\section{Źródla internetowe:}

www.blog.pl

www.blogi.pl

www.blox.pl

www.mvlog.pl

www.iei.notatnik.net

www.lumpiata.blog.pl

www.mvlog.pl

www.opoka.org.pl

www.tenbit.nlog.pl

http://nigri.blog.pl

http://blog.tenbit.pl/gifv-paulii

http://fanaberia-qurrr.blog.onet.pl

http://rozmawiamv.blox.pl 